\title{
Innovation, conformity and other ambivalences in fashion design
}

\section{Amanda Queiroz Campos}

PhD, Universidade do Estado de Santa Catarina / amandaqc88@gmail.com Orcid: 0000-0001-9291-2979 / lattes 


\title{
Innovation, conformity and other ambivalences in fashion design
}

\begin{abstract}
This article problematizes the creation in fashion design. A noticeable majority of companies in the fashion market accompanies trends, which are edited by bureaux de style, disseminated by fashion designers at week runway shows and advertised as successful bets by the fashion media. This investigation results from the development of a research about the agency of fashion designers. The given scope emphasizes the dialectics of creation $x$ adequacy and innovation $x$ security. More specifically, the paper addresses the considerations of three interviewees conducted for the validation of the research's results. During the dialogues which consisted of informal telephone conversations aided by a semi-structured script - the professionals reported their reflections on deliberate acts of creation and the business logic of fashion design corporations.
\end{abstract}

Keywords: fashion design. creation. innovation. 


\title{
Inovação, conformidade e outras ambivalências em design de moda
}

\begin{abstract}
RESUMO
O artigo problematiza a criação no design de moda. Uma maioria notável de empresa no mercado de moda orienta-se por tendências editadas por bureaux de style, disseminada por estilistas em desfiles internacionais ou ainda em apostas de sucesso pela mídia de moda - profissional e/ou entusiasta (amadora). A investigação resulta dos desdobramentos de uma pesquisa sobre a agência de designers de moda. $O$ presente recorte enfatiza as dialéticas criação $x$ adequação $e$ inovação $x$ segurança. De modo mais específico este artigo aborda as considerações de três entrevistadas no momento de validação dos resultados da investigação. Durante os diálogos - que consistiram em conversações informais por telefone, mas tiveram o auxílio de um roteiro semiestruturado as profissionais relataram suas observações sobre atos deliberados de criação e a lógica mercantil das corporações de design de moda.
\end{abstract}

Palavras-chave: design de moda. criação. inovação. 


\title{
La innovación, el cumplimiento y otras ambivalencias en el diseño de moda
}

\begin{abstract}
RESUMEN
El artículo aborda la creación en el diseño de moda. Una notable mayoría de las empresas en el mercado de la moda se guían por las tendencias publicadas por las oficinas de estilo, difundidas por estilistas en desfiles de moda internacionales o incluso apuestas exitosas por los medios de moda: profesionales y / o entusiastas (aficionados). La investigación resulta del desarrollo de una investigación sobre la agencia de diseñadores de moda. El corte actual enfatiza la creación dialéctica $x$ adecuación e innovación $x$ seguridad. Más específicamente, este artículo aborda las consideraciones de tres entrevistados al validar los resultados de la investigación. Durante los diálogos, que consistieron en conversaciones telefónicas informales, pero con la ayuda de un guión semiestructurado, los profesionales informaron sus observaciones sobre actos deliberados de creación y la lógica comercial de las corporaciones de diseño de moda.
\end{abstract}

Palabras clave: diseño de moda. creación. innovación 


\section{INTRODUCTION}

This article aimed to discuss creation and creativity in fashion design practices. With the industrialization of clothing production, which had greater expression in the 1950s and 1960s, the fashion sector organized itself based on the logic of anticipated bets; since production took place from one year to six months before commercialization. Fashion coordinators arose to create coherence between the industry's supply and consumer demand. The bureaux de style institutionalized the figure of coordinators in the 1960s. Their work consisted of creating notebooks with style guidelines based on trends for fashion companies in general.

Many of these bureaux de style maintain their renown and influence to this day. Even in the face of new technologies and the supposed democratization of information, the fashion market continues to be guided by fashion trends published by these companies. When they refuse to pay the subscription fees to the portals, fashion companies follow the trends of renowned designers in fashion shows, in industry magazines, or in other fashion information media such as Instagram and Pinterest.

The current investigation stems from the research ramifications of the doctoral thesis Of tradition and creation (CAMPOS, 2017). It focused on the fashion designers (action) agency in relation to fashion trend research reports. For this article, we sought to extrapolate data from interviews conducted during the result validation stage. On the occasion, three professionals from different occupations in the field of fashion were interviewed. The interview topics involved the relationship between creation $x$ adequacy and innovation $x$ safety and considerations about deliberate acts of creation and the mercantile logic of fashion corporations. 
The theory that supported this investigation and the analysis of the interviews approached the fashion system and market, innovation and innovation in the fashion sector, and, finally, the creative process of fashion products. Therefore, this article mainly addresses the limits of creation and innovation in fashion design. Since designing seems evident in the design activity of the area, fashion designers remain balanced between inventiveness and conformity to both fashion trends and the offer of regular and high-profit products (development of models called bestsellers).

\section{THE FASHION SYSTEM AND FASHION PRODUCTION}

The boundaries between fashion and clothing are difficult to describe precisely. Several authors have tried to demonstrate that not all clothes are fashion products. Likewise, fashion as a phenomenon - usually depictured as a system - goes beyond the contours of clothing and appearance (referred to in English as clothing \& apparel). Researcher Yuniya Kawamura believes that it takes more than clothes to be fashionable. Therefore, industries and the fashion system are more than producers of clothing items. The same is true for all those involved with the design, production, consumption, and communication of fashion products. However, the fashion sector is commonly associated with the textile and apparel industries, in addition to fashion complements, such as the shoe, handbag, and other "fashion" accessory industries.

For a clothing product to be considered a fashion product, it must be associated with the symbolic universe of fashion. This universe is associated with innovation, inventiveness, boldness, sophistication, among others. As the offer of 
apparel products is plentiful, the center of product value creation involves more the incitement of desire and the creation of symbolic value by specialists of branding and marketing (SVENDSEN, 2011). This organization of value creation also rests on legitimacy - since certain brands and people (fashionists) have a greater or lesser degree of influence and validation than others in establishing the canons of style or well-dressing.

The systematic organization of fashion as a business comprises a flow of goods produced in different sectors and stages through complex networks between suppliers and customers, linking the value chain. The value chain represents the various stages of the fashion product production process, with each transformation step adding value to the final product. The material production chain consists of industrial manufacture, that is: spinning, weaving, cutting, sewing and finishing. Cognitive production (creative and commercial) involves research, creation, distribution, sale, brand management, and design management.

Efforts were made to coordinate information and inputs throughout the production chain of the fashion industry. Coordination was born in the context of the industrialization of the production of clothing goods and the growth in demand for them. That, because costs dropped thanks to the possibility of large-scale manufacture. The mass production, however, required anticipation. Therefore, the industrial organization of fashion took place due to a fashion calendar, which organized the flow of fashion information and inputs to the different links in the production chain.

Fashion design scholars generally agree that the fashion industry encompasses the design, manufacturing, distribution, marketing, retail, advertising, and promotion of apparel, from haute couture to mass fashion apparel, 
concentrated by producers of fast fashion - fast fashion (CIARNIENE் \& VIENAZINDIENE், 2014). In all segments, the sector is still guided by coordination, remaining dependent on fashion trends. While trends support continuous creation in fashion, at the same time, they must limit the creations of fashion designers.

As a business, fashion is market-oriented; the largest share of the market operates in response to creations by renowned designers and brands, sales data, and fashion trend information edited by bureaux de style. Because of this, a good part of the offer consists of basic items, traditional products, or strict models dictated by the trend - leaving little or no space for authorial creation.

\section{CREATION AND INNOVATION IN FASHION DESIGN}

German researcher Elke Schüßler (2008) identifies in her doctoral thesis that the market dynamics between supply and demand in the fashion sector falls on Simmel's paradox. The more consumers are exposed to the constant and fast fashion cycles, the greater the need for low-cost products since the stable investment in fast-perishable fashion products is priceless for most consumers. The lower cost of products leads to the need to further reduce product cycles, as the wide availability of fashions reduces their value.

Lithuanian researchers Ciarniene and Viezindiene (2014) came to results similar to those detected by Schüßler. They identified that dynamism and globalization through technology and new management forms made it possible to offer products in shorter cycles to meet peak demand. In turn, this reflects in design actions and the accelerating product launches that require faster and faster decision-making. 
The vast majority of fashion companies have configured themselves to adapt to the accelerated logic and meet the demand by offering numerous products. Thus, research and creation processes were also altered by fashion designers and creative teams, streamlining them. The pressure on designers is such that the term creative unsustainability was coined (BUSINESS OF FASHION, 2015). Therefore, creation remains a current theme in fashion investigations.

\subsection{Management of creation and creativity in fashion design}

Creative industry, fashion is recognized for balancing creativity and business aspects. The creative dimension is poignant in the sector - since the very logic of fashion relies on the aesthetic-symbolic renovation of products in brief fractions of time.

While the creativity and ingenuity of most brands and designers are highly valued in the industry both among competitors and among consumers, the vast majority of companies keep offering commodity products - following the so-called $80-20$ index. That means that only $20 \%$ of the products in the new collections are more inventive or "fashionable" as opposed to $80 \%$ of the total, consisting of basic products or bestsellers from previous seasons, and often common among all international brands (BIOUSSE, 2012).

The management of creativity in fashion companies lies in the association between variability and variety (SAVIOLO \& TESTA, 2015). The balance between the number of products offered and the degree of novelty of such products is imperative. Although it is easier to produce basics items or bestsellers, the degree of differentiation of the brand's

products is associated with its degree of creativity. On the 
other hand, if a product is very fashionable, companies assume that demand is unpredictable (CIARNIENE \& VIENAZINDIENE், 2014).

Despite the high recognition rate of companies considered great fashion creators, such as Maisons de haute couture and prêt-à-porter, commercial fashion products seek to reach the optimum point between standard and trend, commercialization and creativity, between tradition and innovation (CAMPOS, 2017). According to research conducted by Hung and Chen in 2012, the adoption of trend (trendiness) influences the preference for products and intensely affects the apparent perception of a product. When the trend adoption is moderate, there is an increase in the aesthetic preference of the particular product, which indicates the requirement of the ability to combine innovation and typicality in product design.

The research of the Chinese, however, was conducted outside the fashion industry. Therefore, one should consider the specifics of fashion, a field that is closely related to variation and change. Nevertheless, Hung and Chen's results remain interesting for most fashion companies that seek the perfect degree of absorption of aesthetic trends and product normality to attract as many customers as possible. Independent designers and more exclusive brands - referred to by the English term labels - aim for limited production and prefer to develop clothing items with outstanding aesthetic qualities, often regardless of the trends that guide the markets, seeking to profit from the symbolic value of inventiveness and innovation of their projects.

\subsection{Innovation in fashion design}


Innovation became a recurrent theme in the 20th century. In the field of design, the concept gained tone from 1990 onwards. The meanings commonly attributed to the term express: make new; change; introduce new functions; renew. Innovation does not necessarily refer to results but the implementation of a new or improved product or process, method, organization, relationship, among others. (OECD, 2005). Studies show that innovations must be responses to the demands of the market's desires and needs. Innovation works iteratively, adapting products, arranging and rearranging knowledge, tools, and technologies to address these issues.

There are different types of innovation according to their degree of novelty and impact. They may be: incremental, radical, or distinctive. Furthermore, one applies it at different levels: products, processes, positions, and paradigms. Specifically, in fashion, visible changes in clothing are classified as incremental innovation since such "novelties" respond to the stimulus of continuous change and do not cause substantial effects on production and relationships within the fashion industry. Cases of distinctive and radical innovation are scarce in this industry (VERGANTI, 2012), but there are recognized cases of uses of unconventional techniques and materials - which specialists refer to as successful against constant counterfeits.

Devido à maior parte das inovações da moda são associadas ao aspecto estético, autores preferem referir-se às alterações de moda como "novidades" e não como inovações (HANSEN-HANSEN, 2012; BAKEWELL \& MITCHELL, 2006; DHURUP, 2014; HUNG \& CHEN, op. Cit.). Considerando-se a indústria de moda, a novidade é um atributo pertinente, já que faz referência a diferenciação de mercado e atratividade de produto. Além disso, é uma característica considerada 
pelos consumidores diante de uma decisão. A novidade em produtos impulsiona brand consciousness (consciência da marca), lealdade e percepção favorável à marca e aumento do valor do produto (DHURUP, 2014).

Because most fashion innovations are associated with the aesthetic aspect, authors prefer to refer to fashion changes as "novelties" and not as innovations (HANSEN-HANSEN, 2012; BAKEWELL \& MITCHELL, 2006; DHURUP, 2014; HUNG \& CHEN, op. cit.). Novelty is a relevant attribute regarding market differentiation and product attractiveness in the fashion industry. Furthermore, it is a characteristic considered by consumers when making a decision. The novelty in products drives brand consciousness (brand awareness), loyalty, favorable perception of the brand, and increased product value (DHURUP, 2014). However, aesthetic and stylistic innovation does not change the use of a product or its functionality. Innovations in fashion are significant, however, only because of the symbolic value of fashion products. At the height of industrial clothing production, there was an investment in the expansion of consumption based on the aesthetic and symbolic obsolescence of products, which, from a functional point of view, could be used for longer than a fashion season. According to Mozota (2011), consumer satisfaction by subjective and intangible product attributes also infers from innovation, since design-oriented innovation consists of transformations in the meanings attributed by consumers to a product (op. cit.).

The concept of innovation connects to the competitiveness and the success of companies and organizations. It directly influences fashion enterprises because fashion operates by financial and commercial interests (CAMPOS, 2013; GODART, 2006). The production of fashion goods takes place through industrial processes, but fashion inhabits a broader universe 
as it addresses an aesthetic sphere. The consumer goods manufacturing industry materializes the conceptual creations of the fashion culture. The concept production is the place of action for fashion designers, whose activities encompass the planning and development of collections.

\section{PROJECT IN FASHION DESIGN}

Despite recent changes in the production and marketing of fashion products, collections are based on seasonality and defined as a set of products grouped by various criteria, such as technologies, colors, materials, types, markets, and others. For the fashion designer, it is necessary to define a range of colors, shapes, and fabrics to create a balance between the number of products, materials, and details in the collection. The selection will define a unique image and identity and provide consistency to the product mix and the brand, making the proposals cohesive (JONES, 2011).

A fashion design project is systematically defined by its length of two to six weeks and the combination of research activities and design practice (creation). The company's director specifies the concepts, tasks, and objectives of the project (SAVIOLO \& TESTA, 2015). Although there is a range of methodologies for fashion design, many of them have similar and corresponding steps. From a management perspective, Saviolo \& Testa organize the collection's development into four stages: [1] definition of guidelines; [2] structure definition and planning; [3] executive development and [4] evaluation.

The first phase [1] involves defining the general characteristics of the collection, its objectives, and codes and elements of the brand's image. The vast majority of decisions made at this stage arise from data mining research of past collections: sales successes and failures, consumer 
complaints, and praise. Also, market research can suggest changes in the market segment and distribution channels. There is also the possibility of input from the creative team based on trends and new-found themes, presenting data for conceptual and aesthetic aspects of the collection.

After the [2] definition of the collection's structure and planning - which consists of determining commercial and positioning strategies for the brand - and before the [3] executive development - which involves the execution of prototypes, models, and the rational quantification of a load of work and material for each of the production stages creative development takes place. The design stages are central to product development because they involve creativity and innovation. However, they must address commercial guidelines that do not neglect the commitment of fashion companies to the market.

After launching a collection, the [4] evaluation step reconnects the project with the initial step, [1] generating guidelines; since the evaluation provides informational feedback about processes and products, intending to promote improvements in fashion design methodologies, processes, and tools (SAVIOLO \& TESTA, 2015). The purpose of the evaluation is to create collections that are consistent with the market expectations as well as with product requirements and company objectives.

Regarding market expectations, fashion designers must balance permanent and seasonal aspects. Permanent aspects refer to branding and positioning strategies and mid-and longterm decisions about the brand's style identity. In turn, seasonal aspects indicate fashion trends and the ability to gradually introduce market innovations, modernizing the product offer. Based on a greater and lesser degree of adoption of each of these aspects (permanent and seasonal), 
we can consider two extreme poles of the fashion company modalities - in addition to the possibility of gradation between both these poles (Figure 1).

Figure 1. Extreme modalities of fashion companies

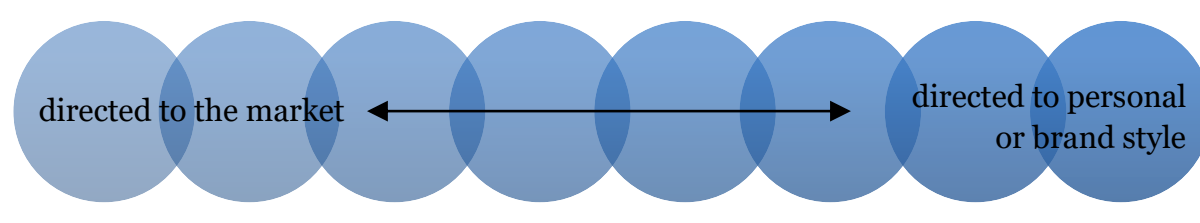

Font: the author

The most market-oriented companies respond broadly to fashion trends and produce quickly in response to the market. Companies that are more focused on a particular and welldefined style - such as haute couture, prêt-à-porter, and authorial designers - are as much based on their tradition and renown as they are more deliberately willing to innovate. Most companies in the contemporary scene are market-driven. Reacting to fashion trends is simpler than creating them. However, designing products that only respond to easily recognizable market opportunities leads to the risk of offering merely trivial products.

Regarding creation in the fashion system, Skov and Melchior (2010) consider that the widespread institutionalization of fashion has routinized interactions, leaving limited space for individual creativity or expressive innovation. Fashion stubbornly relies on models established by the coordination of the fashion system, with various institutions uninterruptedly following the same standards and reinforcing the same structures (CAMPOS, 2017). During the collection development stages, companies choose to follow or adapt some specific trends according to their customers' profiles and the style of their brands. 


\section{METHODOLOGY: INTERVIEWS WITH FASHION SPECIALISTS}

This article exceeds the research developed during the Ph.D. in Design conducted at Universidade Federal de Santa Catarina and Bergische Universität Wuppertal (CAMPOS, 2017). Specifically, the content dealt with consists of the clipping given to the interviews to validate the thesis results. At the time, I resorted to three specialists with diverse activities in the field of fashion: Martina Glomb, professor of Fashion Design at the University of Applied Sciences and Arts of Hannover (Germany); Andrea Bisker, trend researcher and director of WGSN in Brazil for ten years and responsible for its insertion in the country; and Carla Raimondi, journalist, editor and fashion consultant, being editor of Elle and InStyle magazines in Brazil for over 15 years.

Contact with specialists took place informally, directly, or made possible by third parties. The interviews followed informal conversations supported by a semi-structured framework. The script was composed of [1] a brief presentation of the Ph.D. research and questions on [2] fashion trend orientation and [3] on types of use of trend reporting. For the specific purposes of this section, the questions in topic 2 are of interest with an emphasis on subscription to trend services, the use of such information, and questions about creation in fashion design and the sector's mercantile logic.

The interviews were conducted via Skype and were recorded and transcribed with the permission of the interviewees. Transliterations were analyzed qualitatively and in contrast to each other. Content analysis followed the Grounded Theory. Initially proposed by Glaser and Strauss in 1967, the approach implies that theory does not arise simply from the data but the relationship between the researcher and 
the data. Themes of creation, adequacy, innovation and safety emerged from the dialogues with the interviewees, with theory, and with the field of contemporary fashion.

\section{RESULTS: CHALLENGES AND PROGNOSTICS FOR FASHION DESIGN}

Coding the contents of the interview made it possible to organize the information into five major topics: [a] copy $X$ creation; [b] curation; [c] timing; [d] default use of trend reports e; [and] financial aspect. Each of the topics will be further detailed.

The first and broader concept consists of the dialectic [a] copy versus authorial creation. Experts affirm that in the fashion industry, there is less and less room for visceral authorial design. This type of creation - considered more innovative and creative - is also mentioned as a process associated with the ego of designers, who are proud to say that they do not need to search for trends and do not copy them from other designers. Authorial creation is based on difference and is possible only for a minority of creators, usually renowned designers. For other fashion designers, creation involves a more or less moderate mixture of novelty and reproduction of models already developed - by the company itself or other brands.

A more critical view problematizes the copy and paste procedure developed by large department stores, which serve the traditional consumers and those who follow trends. This practice has ancient roots in international trips in which stylists photograph and acquire fashion pieces for their adaptation and reproduction. It would be one of the reasons why the fashion industry is struggling. With limited space for 
creation, designers with less freedom act as reproducers, and those with more freedom act as curators of inspiration.

The concept of [b] curation involves the main work of the fashion designer today. Therefore, good practice requires more relevance than the volume of information. Creatives must act as fashion information filters. To do so, they use this service from providers, such as the great bureaux de style fashion trend research companies. The differential of these providers lies both in the speed with which they offer filtered, personalized, and targeted information to the company's scope (its target audience, positioning, market niche, and product); as in skillful development reliability.

In this investigation, the theme [c] timing followed two lines. The first one concerns the lack of time for designers to research inspirations and trends, even those already filtered by the style bureaux. Fashion creation lost space to bureaucratic tasks. The second line explains the assimilation of novelties by the public. 'Too creative' stylists are positively perceived as ahead of time. However, there is public distrust in adopting innovative products. Many trends adopted by brands were not well accepted by the public, resulting in few sales and reinforcing restraint in the product offering.

Furthermore, experts agreed that fashion companies use trend research reports in [d] default mode. This source of information has become a fixed cost (relatively low, currently) for the vast majority of companies. The fees are justified, as these reports provide relevant information to the sector. Its use involves zapping, collecting, and selecting inspirations and references but not the complete adoption of a closed proposal. It is common practice for stylists to access the material to stay up to date. Trend reports present "validity" and allow stylists to propose novelties to a greater or lesser extent. 
Finally, the last topic refers to the [e] financial aspect of fashion design creation, approached concerning the security of orienting itself to the market. Commercial projects rarely coincide with the creative choices of stylists and designers. However, as most of the public is not looking for very new things, the proposals for more commercials "go with the flow". Adopting trends is seen as valid for a fashion brand when it is restrained, maintaining the most basic and constant proposal.

Interviewees stated that practically very few fashion companies worldwide afford the "luxury" to take risks. Relativizing the adoption of fashion trends would ensure that it is not completely out of consumer expectations, ensuring a higher assertiveness index.

Finally, it is considered to indicate that all specialists referred to the urgent need for research on the topics of dependence on fashion trends reporting, dependence on style and creativity offices, and fashion innovation. Since, as explained, the sector is at an inconvenient moment. This dependence (and the fear of daring and making mistakes) is worrying both internally - on the part of companies and fashion design - and externally - on the part of fashion consumers. Another respected industry expert, trend guru Li Edelkoort (2017), stated in the manifesto titled "Anti-fashion" that the fashion system has become obsolete. Thus, it is up to fashion the courage to recreate itself.

\section{FINAL CONSIDERATIONS}

Products rarely have value in and of themselves. They are evaluated in response to customer wishes. Product attributes are both material - functional, physical, and technical qualities - and immaterial - the consumer's psychological and 
cultural motivations. For a fashion product to reach the consumer, it must go through a double process. One of them has a technical-productive basis and involves the material production of products. The other process corresponds to the creative project. The management of business creativity involves not only the inventiveness of the creative team but also industrial and financial aspects - which have the maintenance of consumers as the main objective, enabling the realization of projects.

The management of creativity and innovation is problematic in the fashion area, as it requires the combination of aesthetic and symbolic aspects with economic and competitive ones. Fashion designers feel pressured to direct their creations to the market since they are evaluated by the company's management due to the acceptance of their products, measured by sales success. Product managers work closely with designers and marketers to provide a clear structure for the creative team to shape next season's demand. Therefore, it is up to the product management to meet the designers' creative intentions and the company's profit expectations with the best possible acuity, maintaining coherence with the various institutions supporting the fashion system.

\section{REFERENCES}

BAKEWELL, Cathy; MITCHELL, Vincent-Wayne. Male versus female consumer decision making styles. Journal of Business Research. v.59, n.12, pp.1297-1300, February 2006. DOI: $10.1016 / \mathrm{j}$. jbusres.2006.09.008

BIOUSSE, Frédéric. Quel avenir pour les tendances? pp.70-79. In: BACRIE, Lydia. (ed.). Qu'est-ce qu'une tendance de mode?. Paris : Fédération Française du Prêt à Porter Féminin, 2012.

CAMPOS, Amanda Queiroz. O mito como incremento do produto na gestão da marca de moda: estudo de imagens gráfico publicitárias das marcas Lança Perfume e Morena Rosa. Dissertação 
de Mestrado. Programa de Pós-Graduação em Design e Expressão Gráfica. Universidade Federal de Santa Catarina. Florianópolis: 2013.

CAMPOS, Amanda Queiroz. Of tradition and creation: the discourse of fashion designers on trend report use. Tese de Doutorado em cotutela. Programa de Pós-Graduação em Design e Expressão Gráfica. Universidade Federal de Santa Catarina \& Doktorprogram in Kunst und Design der Bergischen Universität Wuppertal. Florianópolis/Wuppertal: 2017.

CIARNIENE, Ramune; VIENAZINDIENE, Milita. Management of contemporary fashion industry: characteristics and challenges. Procedia-Social and Behavioral Sciences, v. 156, n. 1, pp. 6368, 2014. DOI: $10.1016 /$ j.sbspro.2014.11.120

DHURUP, Manilall. Impulsive Fashion Apparel Consumption: The Role of Hedonism, Fashion Involvement and Emotional Gratification in Fashion Apparel Impulsive Buying Behaviour in a Developing Country. Mediterranean Journal of Social Sciences, v.5, n.8, pp.168-177, 2014. DOI: 10.5901/mjss.2014.v5n8p168

GODART, Fredèric. Sociologia da moda. [Sociologie de la mode]. São Paulo, SP: SENAC SP, 2010.

EDELKOORT, Li. Anti-Fashion: A Manifesto for the Next Decade I \#BoFVOICES. Disponível em: < https://www.youtube.com/watch?v=LV3djdXfimI >. Acesso em 14 mar. 2018 às 18:18.

HANSEN-HANSEN, Erik. Learning from (luxury) fashion: entrepreneurship and design-led innovation. Proceedings of Innovation Through Design, 2012 International Design Management Research Conference; DMI: Boston, August 8- 9, 2012.

HUNG, Wei-Ken; CHEN, Lin-Lin. Effects of Novelty and Its Dimensions on Aesthetic Preference in Product Design. International Journal of Design. v.6, n.2. pp. 81-90, 2012. Disponível em: <http://www.ijdesign.org/ojs/index.php/IJDesign/article/viewFile/ 1146/474>. Acesso em: 10 jul. 2015.

JONES, Susan Jenkin. Fashion design. 3rd edition. London: Laurence King Publishing, 2011.

KAWAMURA, Yuniya. Fashion-ology: an introduction to fashion studies. 1a reimp. London/New York: Bloomsburry, 2014.

MOZOTA, Brigitte Borja de. Gestão do Design: usando o design para construir valor de marca e inovação corporativa. [Design management]. Porto Alegre, RS: Bookman, 2011.

OECD. Oslo Manual: guidelines for collecting and interpreting innovation data. 2005.2 Disponível em: 
<https://www.oecd.org/sti/inno/2367580.pdf >. Acesso em 10 abr. 2016.

SAVIOLO, Stefania; TESTA, Salvo. La gestión de las empresas de moda. [Strategic Management in the Fashion Companies]. 1a ed. 10a reimp. Barcelona: Gustavo Gili, 2015.

SCHÜßLER, Elke. Strategische Prozesse und Persistenzen: Pfadabhängige Organisation der Wertschöpfung in der Bekleidungsindustrie. Tese de doutorado. Freie Universität Berlin, 2008.

SKOV, Lise; MELCHIOR, Marie Riegels. Research approaches to the study of dress and fashion. In: EICHER, J.O. Berg Encyclopedia of World Dress and Fashion, pp.1-18. Oxford: Berg, 2010.

SVENDSEN, Lars. Filosofia da moda. [Fashion: A Philosophy]. Rio de Janeiro, RJ: Zahar, 2011.

VERGANTI, Roberto. Design-driven innovation: mudando as regras da competição: a inovação radical do significado de produtos. [Design-Driven Innovation: Changing the Rules of Competition by Radically Innovating What Things Mean]. São Paulo: Canal Certo, 2011. 